\title{
Does The Surgical Approach Have an Impact On Treatment Outcomes and Complications in The Surgical Treatment of Pediatric Supracondylar Humeral Fractures?
}

\author{
Pediatrik Suprakondiler Humerus Kırıklarının Cerrahi Tedavisinde Cerrahi Yaklaşımın
}

Tedavi Sonuçları ve Komplikasyonları Üzerine Etkisi Var mıdır?

Fevzi Sağlam ${ }^{1}$, Halil İbrahim Bekler ${ }^{2}$

${ }^{1}$ Consultant Orthopaedic Surgeon. Sakarya University Faculty of Medicine, Adapazarı, Sakarya, Turkey

${ }^{2}$ Consultant Orthopaedic Surgeon. Avicenna International Hospital,Ataşehir, İstanbul, Turkey

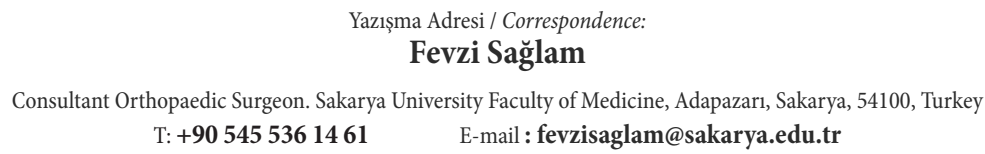

Geliş Tarihi / Received : 23.02.2021 Kabul Tarihi / Accepte: 13.07.2021

Orcid :

Fevzi Sağlam https://orcid.org/0000-0001-9480-0022

Hall İbrahim Bekler https://orcid.org/0000-0002-6314-3143

(Sakarya Tip Dergisi / Sakarya Med J 2021, 11(3):661-668) DOI: 10.31832/smj.885164

\footnotetext{
Öz

Objective In the surgical treatment of supracondylar humerus fractures (SCHF), different treatment methods and surgical incisions depend on the direction of displacement of the distal fragment and the surgeon's experience. This study aimed to compare SCHF treatment results and complications according to closed reduction percutaneous pinning (CRPP) and the surgical approach type and determine the ideal approach.

Materials A retrospective examination was made of a total of 224 patients for this study which was comprising $142(63.4 \%)$ males and 82 (36.6\%) females with a mean age of $5.95 \pm 2.79$ and Methods years (range, 1-13 years). According to the Gartland classification, $58(25.8 \%)$ were Type 2, 166 (74.2\%) were Type 3. We divided the patients included in the study into four groups: medial, lateral, posterior incision, and those who underwent surgery with CRRP. Flynn criteria were used to evaluate the treatment outcomes of patients.

Results The most frequent complications observed were neurological deficit (n:34,15.1\%), scarring (n:32, 14.2\%), subcutaneous pin migration (n:24, 10.2\%), cubitus varus (n:20, $8.9 \%$ ), pin tract infection ( $\mathrm{n}: 15,6.6 \%$ ), flexion restriction ( $\mathrm{n}: 13,5.8 \%)$, extension restriction ( $\mathrm{n}: 12,5.3 \%)$, myositis ossificans ( $\mathrm{n}: 12,5.3 \%)$, and cubitus valgus (n:5, 2.29\%). There were determined to be differences between the group applied with open reduction internal fixation and the closed reduction percutaneous pinning group in respect of complications. No statistically significant difference was found in terms of cosmetic and functional factors according to incision types ( $p>0.05$ ).

Conclusion There is no difference between functional results between closed reduction percutaneous pinning and open surgery groups. In patients who cannot be applied closed reduction, open surgical incisions may be preferred depending on the surgeon's experience and preference.

Keywords Supracondylar humerus fracture; complications; neurological deficit; Flynn criteria
}

Amaç Suprakondiler humerus kırıklarının (SKHK) cerrahi tedavisinde farkh tedavi yöntemleri ve cerrahi kesiler, distal parçanın yer değiştirme yönüne ve cerrahın deneyimine bağlıdır. Bu çalışmanın amacı, SKHK tedavi sonuçlarını ve komplikasyonları kapalı redüksiyon perkütan çivileme (KRPP) ve tercih edilen cerrahi yaklaşım tipine göre karşılaşttrmak ve bu sayede ideal yaklaşımı belirlemektir.

Gereç ve Yas ortalamast 5,95 2,79 (1-13 yas) olan 142 (\% 63,4) erkek ve 82 (\% 36,6) kadın toplam 224 hasta retrospektif olarak incelendi.) Gartland smıflamasına göre 58'i (\% 25,8) Tip 2, 166's

Yöntemle (\% 74,2) Tip 3 idi. Çalısmaya dahil edilen hastaları medial, lateral, posterior insizyon ve KRRP ile ameliyat edilenler olmak üzere dört gruba ayırdık. Hastaların tedavi sonuçlarını değerlendirmek için Flynn kriterleri kullanılmıştır.

Bulgular En stk görülen komplikasyonlar nörolojik defisit (n: 34,\% 15.1), skar (n:32,\% 14.2), subkutan pin migrasyonu (n: 24,\% 10.2), cubitus varus (n: 20,\% 8.9)), çivi dibi enfeksiyonu (n: 15,\% 6,6), fleksiyon ksstlamast (n: 13,\% 5,8), ekstansiyon kısttlaması (n: 12,\% 5,3), miyozit ossifikans (n: 12,\% 5,3) ve kübitus valgus (n: 5,\% 2,29). Açık redüksiyon internal fiksasyonu uygulanan grup ile kapalı redüksiyon perkütan çivileme grubu arasında komplikasyonlar açısından farklllik olduğu belirlendi. İnsizyon tiplerine göre olgularda kozmetik ve fonksiyonel faktörler açısından istatistiksel olarak anlaml farkllik saptanmamıștı $(p>0,05)$.

Sonuç Kapalı redüksiyon perkütan çivileme ve açı cerrahi grupları arasında fonksiyonel sonuçlar arasında fark yoktur. Kapalı redükte edilemeyen kırıklarda cerrahın tecrübesine ve tercihine bağgl olarak açık cerrahi kesiler tercih edilebilir. 


\section{INTRODUCTION}

Supracondylar humerus fractures are the most frequently seen fractures of the elbow in childhood and adolescence. ${ }^{1}$ These fractures are seen most often between the ages of 3 and 10 years and constitute 50\%-70\% of all elbow fractures. ${ }^{1,2}$ Supracondylar humerus fractures constitute two out of three patients hospitalized with the diagnosis of pediatric elbow fractures. According to previous studies, the most commonly damaged nerve is the radial nerve; in more recent studies, the median nerve, especially the anterior interosseous branch, is more often damaged. ${ }^{3,4}$ As there is a high risk of these fractures causing permanent deformity in the elbow and vascular nerve damage, they are considered serious injuries..$^{5-9}$

Open and closed reduction techniques are available for the surgical treatment of pediatric supracondylar humeral fractures. Despite advances in surgical techniques and more energic treatments, the complications associated with these fractures are of specific importance. These include vascular injury, neurological deficit, stiff elbow, myositis ossificans, non-union, avascular necrosis, and angulation deformity. ${ }^{1,3,4}$

This study aims to reveal whether the surgical approaches applied to pediatric supracondylar humerus fractures are superior to each other regarding their effect on treatment results and complications.

\section{MATERIAL and METHOD}

This descriptive, retrospective study was conducted following the Declaration of Helsinki Principles. This study was approved by the Ethics Committee of İstanbul Kartal Dr. Lütfi Kırdar Training and Research Hospital (Date: 03.06.2014, Approval number: 8951330/1009/22).

We were able to access the contact information of 420 patients who were operated on in our clinic between December 2007 and December 2014 with the diagnosis of pediatric supracondylar humerus fractures and 224 patients who came for regular controls were examined and included in our study. Inclusion criteria: a) Patients aged $\leq 13$ years old with post-traumatic supracondylar humerus fracture, b) patients without the metabolic disease, c) Gartland Tip 2 and Type 3 fractures, and d) treated surgically in our clinic. Exclusion criteria: a) conservatively treated supracondylar humerus fractures, b) patients with metabolic disease, c) pathological fracture, d) not operated in our clinic, and e) patients over 13 years old. Risk analysis of the complications that could develop in patients diagnosed with supracondylar humerus fracture was made by evaluating the severity of the trauma causing the fracture, fracture type, fracture displacement, patient age, and time from trauma to presentation at hospital.

Surgery was performed on all Gartland type 3 supracondylar humerus fractures, and open surgery was performed on patients whose reduction was not within acceptable limits after closed reduction trials. All patients with type 2 fractures were applied closed reduction and plaster/splint treatment at the first application, and surgery was applied to patients with reduction loss in control graphs and follow-up. Open surgery with different incisions was applied to patients who could not have closed reduction. According to orthopedists' surgical experience and preference, patients were operated on using medial, posterior, and lateral incisions. Although İn all of our patients, we tried to obtain anatomical reduction during surgery in closed reduction; we considered $\leq 5$ degrees angle and 0 degrees rotation in the coronal and sagittal planes as acceptable during surgery. Therefore, the anatomical reduction was provided by open reduction to all patients with Type 2 and Type 3 supracondylar humerus fractures that are not within acceptable limits in closed reduction.

Postoperatively, neurological and vascular examinations were made, and anterior-posterior and lateral radiographs were taken. The appropriacy of the reduction was confirmed by examining elbows' in respect of the anterior humeral line, the carrying angle, and the Baumann angle. Pa- 
tients were followed up in the ward, and when the swelling decreased, the importance of elevation was explained to the family. After the surgery, the patients were discharged with a long arm cast and recommended outpatient control two weeks later. At the two-week follow-up examination, sutures were removed, and the reduction was checked with radiographs. Kirschner wires (K-wires) that had not migrated under the skin were removed without anesthesia in the clinic in the $3 \mathrm{rd}$ week. K-wires that had migrated subcutaneously were removed under local or general anesthesia. The long arm splint was terminated in the 3 rd week of the patient, and active elbow movements were started.

Preoperatively and postoperatively, findings were examined in respect of nerve or vascular damage. Of the open or closed methods that could be used, if the open reduction was applied, where the incision was made in operation was determined. The preoperative duration (in the first 24 hours after trauma or on which day if later) was determined and in which postoperative week the K-wires were removed. Complications observed in the follow-up examinations and treatments applied were reviewed. Data were retrieved from the radiograph archive records to determine the fracture orientation (flexion or extension) and the Gartland classification type. In extension type Gartland Type 3 fractures, the correlation with displacement direction (posterolateral or posteromedial) and any vascular -nerve damage was examined.

The pre and postoperative radiographs and the early (3rd week and sixth week) and final follow-up radiographs of the fractured side were examined, and measurements were taken of the Baumann angle, carrying angle, and capitohumeral angle and compatibility with the anterior humeral line on the fractured side were assessed. The same orthopedic surgeon took all these measurements. In older children with a closed physis line of the lateral condyle where the Baumann angle could not be measured, the evaluation was made according to the humeroulnar angle. For functional evaluation, patients were called for a final appointment and examined.
Neurological examination was applied to all three nerves of all the patients in the study. At the final follow-up examination, the joint range of movement (ROM) was measured in both elbows of all patients. The open reduction and internal fixation (ORIF) group and the CRPP group were evaluated by comparing the examination findings of the final follow-up examination and the radiographic results concerning functional and cosmetic Flynn criteria. In addition, it was determined at which age and of which gender these types of fractures were more often seen together with additional problems. In cases with neurological findings, evaluations were made of which nerve was most often injured, the correlation between the displacement direction of the fracture and nerve damage, what tests and treatments had been applied during follow-up, and the recovery period of all three nerves.

\section{Statistical Analysis}

Data obtained in the study were analyzed statistically using the Number Cruncher Statistical System (NCSS) 2007 and Power Analysis and Sample Size (PASS) 2008 Statistical Software (Utah, USA). Descriptive statistical methods were used when evaluating the data, and results were stated as mean, standard deviation, median, minimum and maximum values, number, and percentage. In the comparisons of qualitative data, the Pearson Chi-square test and the Fisher-Freeman-Halton test were used. Values of $\mathrm{p}<0.01$ and $\mathrm{p}<0.05$ were accepted as statistically significant.

\section{RESULTS}

The evaluation was made of a total of 224 patients comprising $142(63.4 \%)$ males and $82(36.6 \%)$ females with a mean age of $5.95 \pm 2.79$ years (range, $1-13$ years) (Table 1 ). The demographic distributions of the patients are given in Table 1.

A highly statistically significant difference was determined in the rates of scarring observed according to the incision types $(p=0.001, p<0.01)$ (Table 2$)$. The scarring rate in the posterior incision group was statistically significant- 


\begin{tabular}{|c|c|c|c|c|c|c|}
\hline & & & \multicolumn{4}{|c|}{ Incision } \\
\hline & & & CRPP $(n=89)$ & Lateral $(n=40)$ & Medial $(n=49)$ & Posterior $(n=45)$ \\
\hline \multirow{2}{*}{\multicolumn{2}{|c|}{ Age (years) }} & Mean \pm SD & $6.27 \pm 2.69$ & $5.78 \pm 2.91$ & $5.74 \pm 2.90$ & $5.69 \pm 2.79$ \\
\hline & & Min-Max (Median) & $1-13(6.0)$ & $2-12(6.0)$ & $1-12(6.0)$ & $2-13(5.0)$ \\
\hline \multirow{2}{*}{ Gender } & Female & n (\%) & $33(37.1)$ & $15(37.5)$ & $17(34.0)$ & $17(37.8)$ \\
\hline & Male & n (\%) & $56(62.9)$ & $25(62.5)$ & $33(66.0)$ & $28(62.2)$ \\
\hline \multirow{2}{*}{ Fracture type } & Type 2 & n (\%) & $24(27.0)$ & $16(40.0)$ & $10(20.0)$ & $8(17.8)$ \\
\hline & Type 3 & n (\%) & $65(73.0)$ & $24(60.0)$ & $40(80.0)$ & $37(82.2)$ \\
\hline \multirow{2}{*}{ Side } & Right & n (\%) & $32(36.0)$ & $15(37.5)$ & $20(40.0)$ & $18(40.0)$ \\
\hline & Left & n (\%) & $57(64.0)$ & $25(62.5)$ & $30(60.0)$ & $27(60.0)$ \\
\hline \multirow{2}{*}{\multicolumn{2}{|c|}{ Follow-up duration (months) }} & Mean \pm SD & $36.88 \pm 22.69$ & $37.18 \pm 23.30$ & $40.46 \pm 26.17$ & $45.60 \pm 25.35$ \\
\hline & & Min-Max (Median) & $6.0-90.0(31.0)$ & $6.0-90.0(30.0)$ & $5.0-90.0(31.0)$ & $9.0-90.0(45.0)$ \\
\hline
\end{tabular}

Table 2: Distribution of scarring according to the incision type

\begin{tabular}{|c|c|c|c|c|c|c|c|}
\hline & & & \multicolumn{4}{|c|}{ İncision } & \multirow[b]{2}{*}{ p } \\
\hline & & & CRPP $(n=89)$ & Lateral $(n=40)$ & Medial $(n=49)$ & $\begin{array}{c}\text { Posterior } \\
(n=45)\end{array}$ & \\
\hline \multirow{2}{*}{ Scarring } & Absent & n (\%) & $89(100,0)$ & $39(97,5)$ & $47(94,0)$ & $17(37,8)$ & \multirow{2}{*}{${ }^{\mathrm{a}} 0,001^{* *}$} \\
\hline & Present & n (\%) & $0(0,0)$ & $1(2,5)$ & $3(6,0)$ & $28(62,2)$ & \\
\hline \multirow{2}{*}{$\begin{array}{l}\text { Neurological } \\
\text { Examination }\end{array}$} & Absent & n (\%) & $72(80,9)$ & $34(85,0)$ & $46(92,0)$ & $38(84,4)$ & \multirow{2}{*}{${ }^{\mathrm{a}} 0,381$} \\
\hline & Present & n (\%) & $17(19,1)$ & $6(15,0)$ & $4(8,0)$ & $7(15,6)$ & \\
\hline
\end{tabular}

ly higher than in the CRPP, lateral, and medial incision groups $(\mathrm{p}=0.001, \mathrm{p}=0.001, \mathrm{p}=0.001, \mathrm{p}<0.01)$. In addition, scarring in the medial incision group was determined to be significantly higher than in the CRPP group $(\mathrm{p}=0.045$, $\mathrm{p}<0.05$ ) (Table 2).

In the neurological examination made in the emergency orthopedics clinic, when the patient presented after the trauma, the rate of nerve damage was $6.2 \%$ (n:14), with injury to the anterior interosseous branch of the median nerve seen in $4(1.7 \%)$ cases, injury to the posterior interosseous branch of the radial nerve in $5(2.2 \%)$ and injury to the ulnar nerve in $5(2.2 \%)$. Of the patients who underwent surgery with no preoperative neurological deficit, ulnar nerve damage developed postoperatively (iatrogenic) in 20 cases.

The distribution of pin tract infection of the groups is given in Table 3. All patients who developed pin tract infection were dressed and followed up with antibiotic treatment.

Subcutaneous migration of the K-wires used during surgery was seen at the rate of $10.2 \%$. There was no statistically significant difference between the groups in terms of subcutaneous migration of the pin $(p>0.05)$ (Table 3 ). Therefore, there was no reduction loss in any of our patients due to the pin subcutaneous migration.

The treatment results of the patients were evaluated according to the incision type. The distribution of functional and cosmetic results of the groups according to Flynn criteria is given in Table 3. No statistically significant difference was determined between the groups in respect of cosmetic and functional factors $(\mathrm{p}>0.05)$ (Table 3 ).

Non-union and malunion were not observed in any of the 
Sakarya Med J 2021;11(3):661-668

SAĞLAM et al., Pediatric Supracondylar Humeral Fractures

\begin{tabular}{|c|c|c|c|c|c|c|c|}
\hline & & & \multicolumn{4}{|c|}{ İncision } & \multirow{2}{*}{$\mathbf{p}$} \\
\hline & & & CRPP $(n=89)$ & Lateral $(n=40)$ & Medial $(n=49)$ & Posterior $(n=45)$ & \\
\hline \multirow{2}{*}{ Pin tract infection } & Absent & n (\%) & $82(92.1)$ & $35(87.5)$ & $49(98.0)$ & $43(95.6)$ & \multirow{2}{*}{${ }^{\mathrm{b}} 0.221$} \\
\hline & Present & n (\%) & $7(7.9)$ & $5(12.5)$ & $1(2.0)$ & $2(4.4)$ & \\
\hline \multirow{2}{*}{$\begin{array}{l}\text { Subcutaneous pin } \\
\text { migration }\end{array}$} & Absent & n (\%) & $78(87.6)$ & $37(92.5)$ & $47(94.0)$ & $39(86.7)$ & \multirow{2}{*}{${ }^{\mathrm{b}} 0.546$} \\
\hline & Present & n (\%) & $11(12.4)$ & $3(7.5)$ & $3(6.0)$ & $6(13.3)$ & \\
\hline \multirow{4}{*}{$\begin{array}{l}\text { Flynn Criteria Cosmetic } \\
\text { Factors }\end{array}$} & Poor & n (\%) & $7(7.9)$ & $1(2.5)$ & $1(2.0)$ & $0(0.0)$ & \multirow{4}{*}{${ }^{\mathrm{b}} 0.178$} \\
\hline & Fair & n (\%) & $6(6.7)$ & $6(15.0)$ & $1(2.0)$ & $4(8.9)$ & \\
\hline & Good & n (\%) & $3(3.4)$ & $0(0.0)$ & $2(4.1)$ & $1(2.2)$ & \\
\hline & Excellent & n (\%) & $73(82.0)$ & $33(82.5)$ & $45(91.8)$ & $40(88.9)$ & \\
\hline \multirow{4}{*}{$\begin{array}{l}\text { Flynn Criteria Functional } \\
\text { Factors }\end{array}$} & Poor & n (\%) & $0(0.0)$ & $2(5.0)$ & $5(10.2)$ & $3(6.7)$ & \multirow{4}{*}{${ }^{\mathrm{b}} 0.133$} \\
\hline & Fair & n (\%) & $3(3.4)$ & $2(5.0)$ & $3(6.1)$ & $1(2.2)$ & \\
\hline & Good & n (\%) & $2(2.2)$ & $1(2.5)$ & $1(2.0)$ & $1(2.2)$ & \\
\hline & Excellent & n (\%) & $84(94.4)$ & $35(87.5)$ & $40(81.6)$ & $40(88.9)$ & \\
\hline \multirow{2}{*}{ Myositis Ossificans } & Absent & n (\%) & $87(97.8)$ & $37(92.5)$ & $50(100.0)$ & $38(84.4)$ & \\
\hline & Present & n (\%) & $2(2.2)$ & $3(7.5)$ & $0(0.0)$ & $7(15.6)$ & \\
\hline \multirow{4}{*}{$\begin{array}{l}\text { Displacement direction of } \\
\text { the distal part }\end{array}$} & $\mathrm{AL}$ & n (\%) & $3(3.4)$ & $1(2.5)$ & $3(6.0)$ & $2(4.4)$ & \\
\hline & $\mathrm{AM}$ & $\mathrm{n}(\%)$ & $4(4.5)$ & $2(5.0)$ & $2(4.0)$ & $2(4.4)$ & \\
\hline & PL & $\mathrm{n}(\%)$ & $21(23.6)$ & $8(20.0)$ & $14(28.0)$ & $14(31.1)$ & \\
\hline & PM & $\mathrm{n}(\%)$ & $61(68.5)$ & $29(72.5)$ & $31(62.0)$ & $27(60.0)$ & \\
\hline
\end{tabular}

patients. Myositis ossificans was observed in 12 (5.3\%) patients overall, in 2 (2.2\%) of the CRPP group, in 3 (7.5\%) of the lateral incision group, in 7 (15.6\%) of the posterior incision group, and in no cases of the medial incision group. In 9 of the patients who developed myositis ossificans, as no functional restriction was observed, no surgical procedure was applied, and the myositis ossificans was seen to be resorbed in all of these patients in 18-24 weeks. In 3 patients who developed functional restriction, excision was applied in the 8 th month (Table 3 ).

No statistically significant difference was determined between the incision type groups regarding the rates at which restriction was seen in flexion, extension, pronation, and extension $(\mathrm{p}>0.05)$.

\section{DISCUSSION}

Supracondylar humerus fractures are the most frequently seen fractures of the elbow in childhood, and many approaches are used in treatment. Although closed reduction with percutaneous pinning (CRPP) has been the most preferred approach in surgical treatment in recent years, by approaching the elbow with a lateral, medial, anterior, or posterior incision, supracondylar humerus fractures can be surgically treated. However, there is no consensus in the literature about which incision to use in open reduction. ${ }^{10-15}$

In all the current study patients, closed reduction was attempted first under fluoroscopy guidance, and percutaneous pinning was attempted, and for those where reduction could not be achieved under fluoroscopy, open surgical treatment was applied. In the total 224 patients in this study, neurological deficit was seen in $15.1 \%$, angular deformity (cubitus varus) in $8.9 \%$, scarring (keloid) in 2.2\%, subcutaneous pin migration in $14.2 \%$, vascular complica- 
tions in $0.4 \%$, pin tract infection in $6.6 \%$, myositis ossificans in $5.3 \%$, and compartment syndrome in $0.4 \%$. These treatment results were seen to be consistent with previous findings in the literature.

In several studies, neurological complications in supracondylar humerus fractures have been reported at rates of $10 \%-20 \% .^{10,13,15}$ While the radial nerve was previously reported to be the most commonly injured, Spinner et al. reported for the first time in 1969 that the anterior interosseous nerve was the most commonly injured nerve in extension type supracondylar humerus fractures. ${ }^{4}$ In a study by Lyons et al., it was reported that lesions were observed mostly in the median nerve (58.9\%), followed by the radial nerve $(26.4 \%)$, and at the lowest rate in the ulnar nerve $(14.7 \%)$, and that $80 \%$ of the medial nerve injuries were to the anterior interosseous nerve. ${ }^{16}$

The neurological deficit recovered in all the patients in the current study, and no additional surgical procedure was applied. The most frequent damage seen preoperatively and postoperatively was to the ulnar nerve at a mean of $11.1 \%$. It has been reported in the literature that iatrogenic ulnar nerve damage can be seen at the rate of 2\%-3\% associated with the application of K-wires. ${ }^{12}$ In a series of 72 patients, Flynn et al. reported that postoperative ulnar nerve deficit was seen in only 1 case, which then spontaneously recovered in 6 weeks. ${ }^{17}$

There are extremely large differences between studies in respect of the rates of nerve damage. When it is considered that the most important reason for this could be patient compliance during the neurological examination, as the vast majority of the patients were very young children, this could be attributed to the fact that the neurological examination could not be evaluated more objectively. In the current study, no statistically significant difference was determined between the rates of cases with neurological deficits according to the incision type ( $p>0.05)$.
Non-union or malunion was not observed in any of the current study patients. In literature, pin tract infections have been reported to be seen at the rate of $1 \%-6 \%$ following CRPP in patients with supracondylar humerus fracture. ${ }^{10,18-20}$ In the current study, pin tract infection was determined at the rate of $6.6 \%$ of the whole patient group. In 12 patients who developed pin tract infection, antibiotic treatment was started in the early period. In four patients of these who did not respond to the treatment, the K-wires were removed in the $3 \mathrm{rd}$ postoperative week, then antibiotherapy was continued, and successful results of the treatment were obtained. No statistically significant difference was determined between the patients according to incision type in respect of pin tract infection $(\mathrm{p}>0.05)$.

Cubitus varus deformity is an angular deformity seen after a shifted supracondylar humerus fracture. It was believed in the past that the deformity was not associated with defects originating from the growth plates. It is now known to be due to malunion due to not correcting internal rotation and medial tilt in the coronal plane of the distal fragment associated with inadequate reduction. ${ }^{10-12,21,22}$ In the current study evaluation made of the Baumann angle in the cases according to incision type, no statistically significant difference was determined between the rates of varus observed ( $\mathrm{p}=0.064, \mathrm{p}>0.05)$. However, according to the Baumann angle, the rate of varus was noticeably higher in the CRPP group patients compared to the other groups. No difference was determined between the groups regarding varus observed according to the carrying angle ( $p>0.05)$. This was attributed to the greater comfort and better reduction following open surgery compared to the CRPP procedure.

No statistically significant difference was determined between the cases according to incision type regarding the rates of valgus according to Baumann angle ( $p>0.05)$. In 3 patients who developed an advanced degree of varus deformity, the angular and functional correction was achieved with supracondylar dome osteotomy. 
It has been reported in the literature that myositis ossificans can develop following CRPP and ORIF and is due to aggressive manipulation during exercise. ${ }^{11,12}$ It has also been stated that myositis ossificans is a very rarely seen complication and generally spontaneously resolves within 1-2 years. In the current study, myositis ossificans was seen in $12(5.3 \%)$ patients, 9 of whom had no functional restriction, so no surgical procedure was applied, and spontaneous recovery was observed during follow-up. In the three patients with functional restriction, excision was applied in the 8 th month, followed by single-dose radiotherapy.

Another complication that has not been greatly discussed in the literature is the subcutaneous migration of the K-wires used in surgery. In the current study, subcutaneous K-wire migration was determined at the rate of $10.2 \%$, and no significant difference was determined between patients according to incision type ( $>>0.05)$. In 15 patients aged $>5$ years with subcutaneous pin migration, the $\mathrm{K}$-wires were removed under local anesthesia, and in 8 patients, the K-wires were removed under general anesthesia. As subcutaneous migration of the K-wire is seen at a not inconsiderable rate, it should be considered a very important complication as it requires a second surgical intervention.

In the literature scan performed for this study, it was seen that there was no mention of scarring (keloid), which is one of the cosmetic problems seen in patients following surgical treatment of supracondylar humerus fractures. In the current study, a statistically significantly higher rate of scarring was observed in patients applied with posterior incision, compared to the CRPP patients and those in the lateral and medial incision groups $(\mathrm{p}=0.001, \mathrm{p}=0.001$, $\mathrm{p}=0.001, \mathrm{p}<0.01)$. No surgical treatment was applied to any of the patients who developed scarring during the follow-up period, all were referred to the plastic surgery department, and although surgery was recommended for six patients, the parents of the patients rejected surgery. Var- ious medical treatments were applied to the remaining 26 patients. Although the scar tissue did not create functional restriction, severe cosmetic problems can develop, and these can be considered to create psychological problems, especially as the patients reach adolescence. The posterior approach should be avoided as far as possible to prevent this complication.

According to incision types, the patients' treatment results were evaluated, and no significant difference was determined between the patients according to incision types regarding cosmetic and functional factors $(p>0.05)$. Therefore, there is a need for studies evaluating clinical results with groups with a higher number of cases.

The weakest aspects of our study; 1) our patients who were operated on with anterior incision were not included in our study due to insufficient number, 2) the number of patients who underwent open reduction for different reasons is high.

In conclusion, in respect of the treatment results, as there was no statistically significant difference in the Flynn criteria, although the treatment results of surgery applied with a posterior incision were much better, as there was an increased rate of scarring, medial and lateral incisions should be preferred rather than a posterior incision.

This study was approved by the Ethics Committee of İstanbul Kartal Dr. Lütfi Kurdar Training and Research Hospital (Date: 03.06.2014, Approval number: 8951330/1009/22).

\section{Disclosure statement}

The author affirms there are no conflicts of interest and the author has no financial interest related to the material of this manuscript. 
Sakarya Med J 2021;11(3):661-668

SAĞLAM et al., Pediatric Supracondylar Humeral Fractures

\section{References}

1. Holt JB, Glass NA, \& Shah AS. Understanding the epidemiology of pediatric supracondylar humeral fractures in the United States: identifying opportunities for intervention. Journal of Pediatric Orthopaedics 2018;38(5), 245-51.

2. Hanlon CR, \& Estes JWL. Fractures in childhood-a statistical analysis. The American Journal of Surgery 1954;87(3), 312-23.

3. Cramer KE, Green NE, \& Devito DP. Incidence of anterior interosseous nerve palsy in supracondylar humerus fractures in children. Journal of Pediatric Orthopaedics 1993;13(4), 502-5.

4. Spinner $M$, \& Schreiber SN. Anterior interosseous-nerve paralysis as a complication of supracondylar fractures of the humerus in children. JBJS 1969;51(8), 1584-90.

5. Wendling-Keim DS, Binder M, Dietz HG, \& Lehner M. Prognostic Factors for the Outcome of Supracondylar Humeral Fractures in Children. Orthopaedic surgery 2019;11(4), 690-7.

6. Choi PD, Melikian R, \& Skaggs DL. Risk factors for vascular repair and compartment syndrome in the pulseless supracondylar humerus fracture in children. Journal of Pediatric Orthopaedics 2010;30(1), 50-6.

7. Minkowitz B, \& Busch MT. Supracondylar humerus fractures. Current trends and controversies. The Orthopedic clinics of North America 1994;25(4), 581-94.

8. Kwok IHY, Silk ZM, Quick TJ, Sinisi M, MacQuillan A, \& Fox M. Nerve injuries associated with supracondylar fractures of the humerus in children: our experience in a specialist peripheral nerve injury unit. The Bone \& Joint Journal 2016; 98(6), 851-6.

9. Takahara M, Sasaki I, Kimura T, Kato H, Minami A, \& Ogino T. Second fracture of the distal humerus after varus malunion of a supracondylar fracture in children. The Journal of bone and joint surgery. British volume 1998; 80(5), 791-7.

10. Omid R, Choi PD, \& Skaggs DL. Supracondylar humeral fractures in children. JBJS 2008; 90(5), 1121-32.

11. Hyatt BT, Schmitz MR, \& Rush JK. Complications of pediatric elbow fractures. Orthopedic Clinics 2016; 47(2), 377-85.
12. DeFrancesco CJ, Shah AS, Brusalis CM, Flynn K, Leddy K, \& Flynn JM. Rate of open reduction for supracondylar humerus fractures varies across pediatric orthopaedic surgeons: a single-institution analysis. Journal of Orthopaedic Trauma 2018; 32(10), 400-7.

13. Koudstaal MJ, de Ridder VA, de Lange S, \& Ulrich C. Pediatric supracondylar humerus fractures: the anterior approach. Journal of orthopaedic trauma 2002; 16(6), 409-12.

14. Baydar ML, Aydoğan N, Kırdemir V, Solakoğlu C, Gür E. Çocuk Humerus Suprakondiler Kırılarında Tedavi Prensipleri ve Sonuçları. Hacettepe J Ortop Surgery 1993; 3:124-9.

15. Kumar R, Malhotra R. Medial approach for operative treatment of the widely displaced supracondylar fractures of the humerus in children. J Orthop Surgery 2000; 8(2):13-8.

16. Lyons ST, Quinn M, \& Stanitski CL. Neurovascular injuries in type III humeral supracondylar fractures in children. Clinical Orthopaedics and Related Research $2000 ; 376,62-7$.

17. Flynn JC, Matthews JG, \& Benoit RL. Blind Pinning of Displaced Supracondylar Fractures of the Humerus in Children: Sixteen Years' Experience With Long-Term Follow-Up. JBJS 1974; 56(2), 263-72.

18. Cheng JC, Lam TP, \& Shen WY. Closed reduction and percutaneous pinning for type III displaced supracondylar fractures of the humerus in children. Journal of orthopaedic trauma 1995; 9(6), 511-5.

19. Skaggs DL, Cluck MW, Mostofi A, Flynn JM, \& Kay RM. Lateral-entry pin fixation in the management of supracondylar fractures in children. JBJS 2004; 86(4), 702-7.

20. Boyd DW, \& Aronson DD. Supracondylar fractures of the humerus: a prospective study of percutaneous pinning. Journal of Pediatric Orthopaedics 1992; 12(6), 789-94.

21. Mehlman CT, Strub WM, Roy DR, Wall EJ, \& Crawford AH. The effect of surgical timing on the perioperative complications of treatment of supracondylar humeral fractures in children. JBJS 2001; 83(3), 323.

22. Kropelnicki A, Ali AM, Popat R, \& Sarraf KM. Paediatric supracondylar humerus fractures. British Journal of Hospital Medicine 2019; 80(6), 312-6. 